\title{
Sitaattien tehtävät ja tekeminen kaunokirjallis-journalistisissa lehtijutuissa
}

Sitaatit ovat lehtijuttujen kerronnan keskeinen mutta vähän tutkittu elementti. Tässä artikkelissa etsin vastausta siihen, mitä tehtäviä sitaateilla on. Artikkelini viitekehys on journalismintutkimuksessa, mutta analyysissani on myös narratologinen ja kielitieteellis-pragmaattinen ulottuvuutensa. Kuudesta kaunokirjallis-journalistisesta lehtijutusta koostuvalle aineistolleni tekemäni narratiivisen tekstianalyysin tuloksena kaunokirjallis-journalististen lehtijuttujen sitaatit 1) luovat jutun rakenteeseen rytmiä tekstin tasolla, 2) ovat yksi juonta eteenpäin vievä kerronnan elementti, 3) kertovat tapahtumien fyysisestä ja/tai sosiaalisesta ympäristöstä, 4) luovat uskottavuutta sille, että johtoilmauksen identifioima henkilö on sanonut sanatarkasti referoidulla tavalla, 5) välittävät ensikäden tietoa referoitavan henkilön kokemuksista ja hänen ainutlaatuisesta tavastaan käyttää kieltä ja 6) luonnehtivat puhujaa, mikä tapahtuu paitsi sen kautta, mitä sanotaan, ennen kaikkea sillä, miten sanotaan. Tehtävät eivät ole toisiaan poissulkevia, vaan jokaisessa sitaatissa on potentiaali näiden kaikkien tehtävien ilmentämiseen. Artikkelini alatutkimuskysymyksenä kartoitan ammattikirjallisuuden ja teemahaastattelujen avulla muokkausprosessista vallitsevia käsityksiä siitä, miten puhetta tulisi kirjallisiksi sitaateiksi muokata. Yleinen tapa näyttää olevan, että puhutun kielen piirteitä karsitaan, tekstin sidoksisuutta täsmennetään ja eri tilanteissa saatuja lausuntoja yhdistetään - kunhan sitaattien autenttinen konteksti ja kronologia säilyy suhteessa juttuun (mahdollisesti) kirjoitettuun lokaatioon. Lopuksi suhteutan sitaattien tehtäviä ja tekemistä - erityisesti niihin liittyviä eettisiä kysymyksiä - ajankohtaiseen keskusteluun journalismin taloudellisesta ja sisällöllisestä murroksesta.

AVAINSANAT: sitaatti, kaunokirjallis-journalistiset lehtijutut, editointi, toimitustyö

itaatit ovat keskeinen osa nykypäivän lehtijutun konventiota (mm. Clayton 1994; Siivonen 1999). Lyhyttä uutista lukuun ottamatta lehtijutut ovat täynnä sitaatteja, oli repliikin lausuja sitten jutun päähenkilö, käsiteltävän aihealueen asiantuntija tai pelkkä ohikulkija. Tämä artikkeli kysyy, mitä tehtäviä puheesta tehdyillä sitaateilla lehtijutuissa on. 
Vaikka sitaatit ovat lehtitekstin perusraaka-ainetta, alan kotimaisessa oppikirjallisuudessa sitaattien tehtäviä ei juuri tarkastella. Eräs vanhimpia suomalaisia toimittajantyön oppaita on Jorma Miettisen Toimitustyö (1984). Teos käsittelee sekä lehti-, radioettä televisiotyötä, ja painotus on uutisjournalismissa. Lehtijutun sitaateista kirjoitetaan jotakuinkin tämän verran:

Uutis- ja ajankohtaisohjelmissa on tyypillisintä, että haastattelua käytetään haastateltavan sanottavan dokumentointikeinona. Antamalla haastateltavalle tilaisuus vastata tärkeään kysymykseen omalla äänellään radiossa ja omalla äänellään ja kuvallaan televisiossa tämä haastatteluosuus toimii myös dokumenttina. Kuulija ja katsoja voi vakuuttua siitä, että haastateltava on varmasti antanut sanotunlaisen lausunnon. Tällainen lisää myös tiedotusvälineiden luotettavuutta. Tätä mallia lehdistössä vastaa haastateltavan lausunnon sanatarkka lainaus eli sitaatti, joka osoitetaan lukijalle laittamalla lainattava osa sitaatteihin ("....") tai käyttämällä sen alussa ranskalaista viivaa(-....) (emts.156, lihavointi kirjoittajan.)

Miettisen näkemys rajoittuu sitaatin luotettavuutta luovaan funktioon, mikä onkin epäilemättä sitaattien keskeinen tehtävä (esim. Brooks ym. 2002; Scanlan 2000). Kun lukijan on sitaatin kautta mahdollista vakuuttua, mitä haastateltava on sanatarkasti sanonut, syntyy lehtijuttuun journalismilta edellytettävä puolueettomuuden ja objektiivisuuden vaikutelma: sitaattina esitettyyn lausuntoon toimittajan oma asennoituminen ei vaikuta (Nylund 2006, 155); sitaateissa kertoja-toimittajan ääni ja valta tekstiin ja referoitavaan henkilöön ovat vähäisimmillään (Kalliokoski 2005, 18); sitaatteja käytetään usein luomaan etäisyyttä lehden ja lainatun henkilön tai mielipiteiden välille (Van Dijk 1988, 136).

Läheskään aina tämä ei kuitenkaan riitä perustelemaan sitaattia. Erityisesti aikakauslehtien suosimissa juttutyypeissä kuten henkilöhaastatteluissa ja reportaaseissa sitaateilla tuntuisi olevan muitakin tehtäviä kuin vakuuttaa "tärkeisiin kysymyksiin" saadut vastaukset autenttisiksi. Tom Lundbergin Tuhannen taalan juttu (1992) on harvoja nimenomaan aikakauslehtijournalismiin keskittyviä kotimaisia oppaita. Myös siinä sitaattien tehtävistä kirjoitetaan niukalti:

Sitaatit luovat juttuusi läsnäolon tuntua. Repliikit helpottavat myös lukemista, kuljettavat tekstiäsi, ilmavoittavat tiivistä kerrontaa ja tuovat juttuusi ihmisten ääniä. (Emts. 74.)

Silloinkin kun sitaattien tehtävistä on kirjoitettu enemmän - mikä koskee lähes yksinomaan angloamerikkalaisissa maissa julkaistuja kirjoitusoppaita - niiden tarkempi käsittely jää toisistaan irrallisia ranskalaisia viivoja sisältävien listausten tasolle (esim. Blundell 1988; Brooks ym. 2002; Lanson \& Stephens 2008; Nylund 2006). Hypoteettinen lähtökohtani tälle artikkelille on, että sitaattien tehtävät eivät ainoastaan vaihtele sitaatista toiseen, vaan kullakin sitaatilla on useita eri tehtäviä.

Sitaattien tehtävistä lehtijutuissa ei ole kovinkaan paljon tutkimusta. Mats Nylund (2006) on tutkinut sanomalehtiuutisten sitaatteja kerrontaa konstruoivina element- 
teinä. Hänen mukaansa sitaatit joko jakavat tai kommentoivat jutun ensisijaista näkökulmaa, niitä siis käytetään joko monologisessa tai dialogisessa suhteessa kerrontaan. Ensimmäisessä tapauksessa sitaatit tuovat juttuun uuden tai uusia ääniä, jotka kuitenkin täydentävät ja tukevat toimittaja-kertojan näkökulmaa. Jälkimmäisessä tapauksessa eri henkilöiltä saadut sitaatit asetetaan vastakkain ikään kuin ne kommentoisivat toisiaan, vaikkei niitä alkuperäisessä puhetilanteessa ole välttämättä sillä tavoin kohdistettu. Näin juttuun luodaan myös näennäistä objektiivisuutta, onhan toimittaja ottanut molempien osapuolten kannat esille. (Nylund 2006.)

Jonita Siivonen (2007) on tutkinut väitöskirjassaan henkilöhaastattelujen henkilökuvaa luovia tekstuaalisia keinoja, Maria Lassila-Merisalo puolestaan sekä väitöskirjassaan (2009) että pro gradussaan (Lassila 2001) kaunokirjallista journalismia, sen luonteenpiirteitä sekä suhdetta faktaan ja fiktioon. Luonnollisesti kummankin töissä myös sitaattien rooli nousee esiin. Emmi Nissi (2010) on tutkinut feature-juttujen muotokieltä ja määritellyt sitaatin ja dialogin yhdeksi featurelle tyypillisistä ilmaisukeinoista. Kielitieteilijä Henna Makkonen-Craig on tutkinut puhekielen illuusiota lehtijuttuihin luovia keinoja sekä kvantitatiivisesti että kvalitatiivisesti (1996) ja syventynyt sitaattien kielenpiirteisiin (uutis)lehtijutuissa (1999). Jälkimmäisessä hän pohtii sivumennen myös sitaattien tehtäviä, joskin joutuu toteamaan, että "the why-question is more complex than may at first appear, and is outwith the scope of this paper" (emts. 138).

Käsillä olevan artikkelin pääasiallinen viitekehys on journalismintutkimus, josta lainaa käsitteistöä niin analyysini kuin jo kaunokirjallis-journalistisen kontekstin määrittelykin (esim. Hemánus 1990; 1995). Toisaalta käsittelyssäni on myös narratologinen' (esim. Genette 1980 [1972]; Koskimies 1962; Rimmon-Kenan 1991 [1983]; Tammi 1992) ja kielitieteellis-pragmaattinen ulottuvuutensa, joista jälkimmäisessä tutkimuskohteena ei ole kieli sellaisenaan vaan kielen muodon ja käyttötarkoituksen välinen suhde - se, mitä kielellisellä ilmauksella tavoitellaan (Tainio 1997; Tiittula 1992).

Päätutkimuskysymyksenäni tutkin, mitä tehtäviä sitaateilla kaunokirjallis-journalistisissa lehtijutuissa on. Tähän kysymykseen vastaan lehtijuttuaineistolle tekemäni tekstianalyysin perusteella. Alatutkimuskysymyksenäni etsin ammattikirjallisuusaineiston sekä teemahaastatteluiden kautta vastausta siihen, millä tavoin puhetta tulisi kirjallisiksi sitaateiksi muokata.

\section{Sitaatti ja sen suhde puheeseen}

Sitaatti koostuu kahdesta osasta: referaattiosasta ja johtoilmauksesta. Ensin mainittu on toisinto alkuperäisestä lausunnosta, ja se erotetaan muusta tekstistä lehteen valitun käytännön mukaisesti joko lainausmerkeillä tai sitaattiviivalla. Jälkimmäinen puolestaan kertoo, ketä referoidaan, miten hän on asiansa sanonut ja kenelle kohdistanut - tai ainakin jotain edellisistä. (ISK § 1459.) Tässä artikkelissa keskitytään sitaatin referaattiosan tehtävien analysointiin. Johtoilmausten tehtäviä olen käsitellyt toisaalla (ks. Haapanen 2010) ${ }^{2}$. 
Sitaattia eli kielitieteellisin termein suoraa esitystä (1) ja sen vastinparia epäsuoraa esitystä (2) voidaan pitää referoinnin universaaleina pääluokkina (Kuiri 1984):

1) Suora esitys: "Mie oon mies", sanoi mies.

2) Epäsuora esitys: Mies sanoi, että hän oli mies.

Kumpikin esitystapa välittää referoitavan lausunnon sisällön. Erona on, että siinä missä epäsuora esitys kertoo, suora esitys näyttää; suora esitys siis välittää sanatarkasti alkuperäisen puhujan käyttämät sanat ja rakenteet. Mauno Koski $(1985,76)$ on kuitenkin huomauttanut, ettei kyse ole loppujen lopuksi siitä, että suorassa esityksessä kyettäisiin tai välttämättä haluttaisiinkaan toistaa alkuperäinen ilmaus sellaisenaan, vaan siitä, että suoran esityksen keinoin luodaan vaikutelma autenttisuudesta (tarkemmin referoinnista suomen kielessä ks. Haakana \& Kalliokoski 2005). Juuri tähän suoran esityksen ilmaisukykyyn monet sitaatin tehtävistä tämän artikkelin perusteella perustuvat.

Tässä artikkelissa tarkastellaan haastateltavan puheesta tehtyjä sitaatteja, vaikka sitaatteja on toki mahdollista tehdä myös kirjallisesta alkutekstistä. Puhesitaattien kohdalla on muistettava, että puheen ja kirjoitetun kielen suhde on kompleksinen: ääniaalloilla välitettävän puheen ja grafeemeina paperille toteutettavan kirjoituksen välillä ei ole mitään absoluuttista vastaavuussuhdetta. Vaikka tämä erimitallisuus sivuutettaisiin ja katsottaisiin, että puhe on yksi yhteen kirjoitetuksi siirrettävissä, ei ongelma suinkaan poistu. Puhuttu ja kirjoitettu kieli nimittäin eroavat toisistaan niin äänne/kirjoitusasun kuin usein myös lauserakenteen ja sanaston perusteella (esim. Tiittula 1992). Lisäksi merkittävä osa puheesta tehtävistä tulkinnoista perustuu puhujan äänen prosodiaan eli äänen väriin, korkeuteen ja nopeuteen, eleisiin, ilmeisiin, katseeseen - jo pelkästään suun liikkeiden näkemiseen (McKee 1998). Näiden kielenpiirteiden välittämiseen kirjoitettu kieli kykenee huonosti, monilta osin ei ollenkaan.

Puheen siirtäminen kanavalta toiselle, puheesta kirjoitetuksi, ei ole mekaaninen operaatio, vaan se vaatii tietoisia valintoja. Tämän muokkaamisprosessin kulkuun ei toimialalla - niin toimitustyön oppikirjojen, muun alan kirjallisuuden kuin toimittajienkaan keskuudessa - ole julkilausuttua, yhteiseksi sovittua ohjeistusta (Järventaus 1996; Scanlan 2000; lehtivalokuvan kuvankäsittelyn suhteen tilanne on vastaava ks. Hujanen 2009). Alatutkimuskysymyksenäni tässä artikkelissa kartoitankin vallitsevia käsityksiä puheen muokkaamisesta sitaateiksi

\section{Aineistot ja menetelmät}

Tutkin sitaatteja lehtijutuissa, joka on kuitenkin laaja ja rajoiltaan epäselvä käsite. Sen prototyyppisimpänä ja vanhimpana muotona voidaan pitää uutista, nimenomaan uutissähkettä (Bruun ym. 1986), jonka toteavaan ja kantaaottamattomaan kerrontaan sitaatit eivät lähtökohtaisesti edes kuulu. Uutisen sijaan olenkin halunnut lähteä analysoimaan sitaatin tehtäviä runsaasta ja hedelmällisestä maastosta ja valinnut kon- 
tekstiksi kaunokirjallis-journalistisia piirteitä sisältävät lehtijutut. Käsite kaunokirjallis-journalistinen lehtijuttu perustuu Maria Lassila-Merisalon (2009; Lassila 2001) määrittelylle, joskin yhdellä merkittävällä erotuksella: en pidä kaunokirjallisia keinoja hyödyntäviä journalistisia tekstejä itsenäisenä lajityyppinä kuten Lassila-Merisalo - joka kylläkin sanoo tehneensä niin "selkeyden ja yksinkertaisuuden vuoksi" $(2009,14)$ - vaan juttuina, joissa kaunokirjallisia piirteitä on enemmän tai vähemmän.

Käsiteparin jälkimmäinen osa, journalismi, viittaa siihen, että kaiken jutussa esitetyn täytyy olla faktaa eli tosiasiapohjaista sekä objektiivista sikäli, että lukijan on mahdollista arvioida esitettyjen asioiden olennaisuus kokonaisuuden kannalta. Käsiteparin alkuosa, kaunokirjallisuus, viittaa puolestaan jutun muotoon. Lassila-Merisalo ottaa kaunokirjallisen muodon "antiteesiksi" uutisen: erotuksena uutisen pyramidirakenteesta (ks. esim. Bruun ym. 1986; Kotilainen 1989; Miettinen 1984; Rentola 1983; Tervonen 1986) kaunokirjallista rakennetta voidaan ajatella yhtenä isona kaarena, joka ei pyri paljastamaan olennaista heti ensimmäisessä lauseessa vaan - hieman karrikoiden - vasta loppuhuipennuksena (ks. esim. Kramer \& Call 2007; Rentola 1983; Stein 1995). Ero näkyy myös kertojassa: siinä missä uutisen kertoja on perinteisesti näkymätön ja läsnäolematon, kaunokirjallisen journalismin yhtenä selvimmistä tunnusmerkeistä voidaan pitää kertojan subjektin näkymistä tekstissä (Lassila-Merisalo 2009; Lassila 2001). Eroa voidaan tarkastella myös kerronnan perusmuotojen kautta: uutinen on lähtökohtaisesti "asiallista ja yleistävää selostamista" (Palmgren 1986, 206), kaunokirjallinen muoto sen sijaan hyödyntää myös kuvausta, dialogia, eeppistä tilannetta ja kohtausta sekä joskus eläytymisesitystä ja tajunnanvirtakuvausta (emts. 205-221). Pohjimmiltaan uutisen ja kaunokirjallisen muodon ero juontuu lukijan odotuksista tekstiä kohtaan: uutisen tehtävä on jakaa tietoa, kaunokirjallisen tekstin elämyksiä (Miettinen 1984; Okkonen 1974; Hemánus 1990; Clark 2006; Kauppinen \& Laurinen 1988).

Koska kaunokirjallis-journalistiset lehtijutut ovat heterogeeninen ja rajoiltaan epämääräinen joukko, olisi laajankin aineiston perusteella hankalaa esittää määrällisiä johtopäätöksiä sitaattien erilaisten tehtävien esiintymistiheyksistä. Siksi olen keskittynyt sitaattien tehtävien laadulliseen analysointiin. Vaikka kaunokirjallisia keinoja hyödynnetään hyvin monenlaisissa journalistisissa julkaisuissa, runsainta ja monipuolisinta niiden käyttö on aikakauslehdissä. Aineistoksi olen valinnut kuusi laajaa kaunokirjallis-journalistista lehtijuttua Helsingin Sanomien Sunnuntai-sivuilta ja Kuukausiliitteestä, Valituista Paloista (2 juttua), Imagesta ja Suomen Kuvalehdestä. Käsitykseni mukaan nämä lehdet julkaisevat kaunokirjallis-journalistisia juttuja säännöllisesti, minkä lisäksi ne hyödyntävät kaunokirjallisia keinoja jutuissaan monipuolisesti ja paneutuneesti (ks. myös Lassila 2001; Nissi 2010). Olen määritellyt kaunokirjallis-journalististen juttujen sitaattien tehtävät narratiivisen tekstianalyysin keinoin. Narratiivinen tekstianalyysi etsii niitä tekstin eritasoisia komponentteja, joista kertomus rakentuu (Genette 1980 [1972]). Tutkimuskysymykseni asettelun vuoksi analyysini on lähtenyt liikkeelle yhdestä kertomuksen komponentista, sitaatista, ja määritellyt sen funktioita suhteessa kokonaisuuteen, kertomukseen eli leh- 
tijuttuun. Käytännössä tekstianalyysini on edennyt paitsi kunkin sitaatin sisältöä ja kieltä tarkastelemalla, myös sitaatin laajempaa tekstikontekstia vasten.

Alatutkimuskysymykseeni olen vastannut ammattikirjallisuuden ja alan toimijoiden teemahaastattelujen perusteella, joskin kommentoin tämän aineiston avulla myös päätutkimuskysymykseni tuloksia. Ammattikirjallisuusaineistoni nelisenkymmentä toimitustyön ja journalistisen kirjoittamisen opasta on julkaistu Suomessa, Yhdysvalloissa ja Iso-Britanniassa. Oppaiden valinnassa en ole ollut kovin tiukkarajainen: lähestymistapa on monessa oppaassa yleisjournalistinen, vaikka mukaan mahtuu myös nimenomaan kaunokirjallis-journalistiseen kirjoittamiseen keskittyneitä oppaita (esim. Blundell 1988; Flaherty 2009; Kramer \& Call 2007). Alatutkimuskysymyksen tuloksia esittäessäni viittaan oppaisiin lähinnä silloin, jos kyseinen asia on esitetty vain tietyssä oppaassa tai erityisen omaperäisesti.

Teemahaastatteluja tein kuusi. Valitsin haastatteluihin toimittajia, joilla on laajaa kokemusta nimenomaan kaunokirjallis-journalistisiksi määriteltävien juttujen kirjoittamisesta, editoinnista ja monilla myös opettamisesta. Teemahaastatteluissa kysymykset esitettiin nimenomaan kaunokirjallis-journalistista juttutyyppiä koskien. Vaikka käsite ei ole vakiintunut eikä selvärajainen, haastateltavat ymmärsivät hyvin, millaisia juttuja käsitteellä tarkoitin. Muodoltaan haastattelut olivat vapaita: Haastattelusta puhelimessa ja sähköpostilla sovittaessa esittelin lyhyesti, mistä tutkimuksessani on kyse. Mitään etukäteisvalmisteluja en pyytänyt enkä olettanut haastateltavien tekevän - halusinhan selvittää nimenomaan vallitsevia käsityksiä. Haastattelutilannetta varten laadin käsiteltävistä aihepiireistä väljän listan, jonka pohjalta keskustelu sai rönsyillä (teemahaastattelusta tarkemmin ks. Hirsjärvi \& Hurme 2008). Kaikki haastattelut tehtiin maalis-kesäkuussa 2009, ja työsuhdetiedot ovat kyseisiltä ajankohdilta. Tapasin jokaisen haastateltavan kerran, ja haastattelut kestivät tunnista kahteen. Haastattelut taltioin nauhoittamalla.

Aineiston kerättyäni merkitsin sitaattien muokkaamiseen liittyvät näkemykset ja ryhmittelin ne sisällön perusteella. Ryhmittely onnistui varsin jäännöksettömästi ja selvärajaisesti. Lopuksi valitsin näkemyksistä yleisimmät, jotka esittelen tässä artikkelissa kartoitukseni tuloksina.

\section{Sitaattien tehtävät}

Määrittelin analyysini perusteella sitaateille kaunokirjallis-journalistisissa lehtijutuissa kuusi päätehtävää, jotka laajenevat edelleen alatehtäviin. Sitaatin tehtävät eivät ole toisistaan irrallisia funktioita, vaan niistä rakentuu hypoteesini mukaisesti jatkumonomainen funktioiden spektri. Sen yhtenä ääripäänä on sitaatin fyysinen, jutun rakennetta luova tehtävä. Jatkumo etenee sellaisiin sitaatin tehtäviin, joiden teho perustuu tekstin propositionaaliseen eli suorasanaiseen merkitykseen, ja päätyy lopulta sitaatin abstrakteihin tehtäviin, joiden toteutumisessa oleellista ei ole se, mitä sitaatissa sanotaan, vaan miten se sanotaan. Seuraavassa esittelen sitaatin tehtävät lyhyesti. 
1. Rakentaa rytmiä. Sitaatti on lehtijutussa rakenteellisesti kohosteinen elementti. Se rytmittää juttua samaan tapaan kuin esimerkiksi tekstin jaksot, kappaleet ja virkkeet.

2. Kuljettaa juonta. Lehtijutussa tarina kerrotaan juonen esittämällä tavalla. Sitaatit ovat yksi juonta eteenpäin vievä kerronnan elementti.

3. Kertoo ympäristöstä. Sitaateilla kirjoittaja vahvistaa illuusiota sekä juttuun kirjoitetusta fyysis-ajallisesta tapahtumapaikasta että sosiaalisesta ilmapiiristä, tunnelmasta ja ihmisten välisen kommunikoinnin laadusta.

4. Luo uskottavuutta. Sitaatti luo uskottavuutta sille, että johtoilmauksen identifioima henkilö on sanonut sanatarkasti referoidulla tavalla.

5. Välittää ainutkertaisuutta ja omakohtaisuutta. Sitaatti kertoo referoitavan henkilön ainutlaatuisesta tavasta käyttää kieltä. Sitaatti myös välittää ensikäden tietoa hänen kokemuksistaan.

6. Luonnehtii puhujaa. Sitaatin propositionaalinen merkitys kertoo, mitä sanotaan, mutta se, miten sanotaan, luonnehtii aina tavalla tai toisella puhujaa itseään.

Huomionarvoista on, että sitaatin tehtävät eivät ole toisiaan poissulkevia, vaan ne tarkastelevat sitaattia eri tasoilla. Yksittäinen sitaatti ei siis asetu vain johonkin tehtäväkategorioista, vaan lähtökohtaisesti siinä on potentiaali kaikkien tehtävien ilmentämiseen. Jutun konteksi lopulta määrittelee, mikä tai mitkä funktioista pääsevät kerronnassa reaalistumaan, mitkä puolestaan jäävät sivuosaan tai toteutumatta. Seuraavaksi syvennyn kuhunkin kuudesta sitaatintehtävästä tarkemmin ja selvennän esitystäni aineistoesimerkein.

\section{Sitaatti rakentaa rytmiä}

Jokaisen lehtijutun fyysisessä rakenteessa on jonkinlainen rytmi, toisistaan selkeästi erottuvien elementtien muodostama vaihtelu. Tällaisia elementtejä ovat esimerkiksi alku ja loppu, anfangeilla tai väliotsikoilla erotetut jaksot sekä kappaleet ja edelleen virkkeet. Yksi tekstimassaa jaksottava elementti ovat sitaatit, jotka ovat leipätekstistä usein kohosteisena erottuva tekstiaines (Hennessy 1989; Rentola 1999; Nousiainen 1998; Rosma 1984; Silfverbergin haastattelu). Tavallista on, että sitaatti mahdollisine johtoilmauksineen erotetaan leipätekstistä omaksi kappaleekseen.

Fyysinen rytmi. Leipätekstin ja sitaattien luoman rytmin havainnollistamiseksi seuraavassa on katkelma liikemies Harry "Hjallis" Harkimosta kertovasta henkilökuvajutusta (HS Kuukausiliite 11/2003) hyvin pienessä kirjasinkoossa. Olen mustannut tekstimassasta sitaattien referaattiosat. Jotta visuaalinen vaikutelma vastaisi alkuperäistä lehtikontekstia, olen asetellut tekstin kapeille palstoille. 

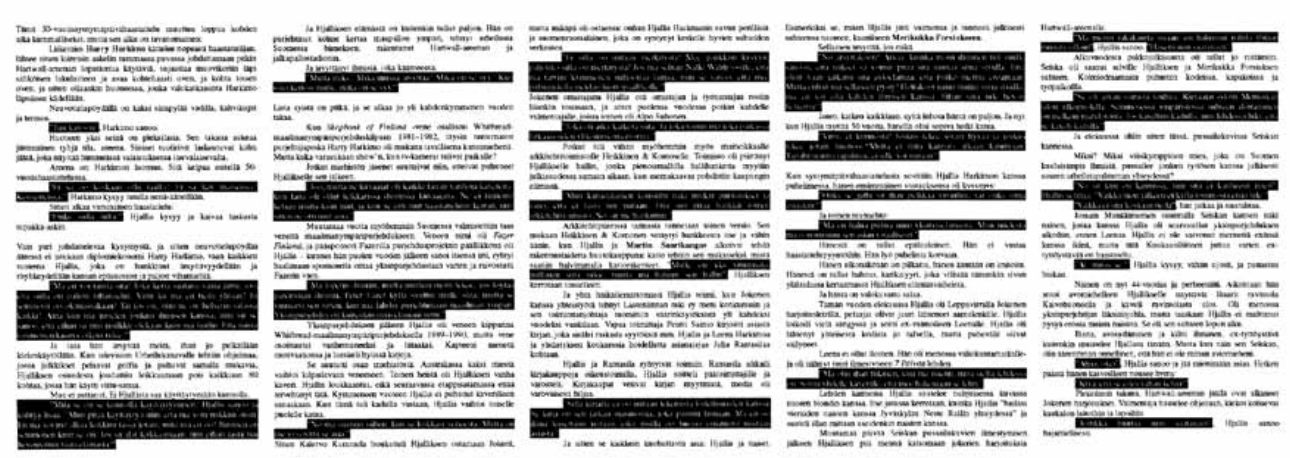

Kuva 1. Graafinen esitys sitaattien rakennetta luovasta tehtävästä.

Esimerkkikatkelma hahmottuu tekstin sijaan mustavalkoisena kuvana, jossa leipätekstistä rakentuva vaalea tekstuuri vuorottelee sitaattien luoman tumman tekstuurin kanssa. Näin tarkasteltuna on helppo huomata, millaista vastakkaisten elementtien vaihtelua sitaatit jutun makrorakenteeseen luovat.

Toki rytmiikkaa tekevät myös monet muut jutun elementit, joten halutessaan edellisen kaltaisen mustavalkografiikan voisi vedostaa monin muinkin kriteerein. Muun muassa Roy Peter Clark $(2006,128)$ on kuitenkin huomauttanut, että nimenomaan sitaatit ja niiden avulla luotu dialogi tarjoavat tekstimassaan lukijan silmää houkuttavan ja virkistävän "ilmavan vaalean tilan".

Ilmaisullinen rytmi. Vaikka periaatteessa sitaatit voivat imitoida onomatopoeettisesti esimerkiksi moottorin ääntä tai hevosen hirnuntaa, käytännössä ne ovat lähes yksinomaan lainausta ihmisen puheesta. Lainausmerkit siis ilmoittavat, että "tässä kohdin tekstiä kertoja väistyy ja päästää lukijan suoraan kontaktiin tarinan henkilön kanssa, kuuloetäisyyden päähän ihmisestä" (Riikinsaaren haastattelu; ks. myös esim. Brooks ym. 2002; Harrigan 1993). Kanavan vaihtuminen kirjallisesta ilmaisusta puheeksi - joskin kirjoitetuksi sellaiseksi - antaa sitaatille uudenlaisen rakenteellisen tehtävän: se luo kirjalliseen esitykseen puhutun kommunikoinnin vaikutelmaa.

Vielä kymmenen vuotta sitten moni saattoi ajatella, että muistiongelmat ovat tiededokumenttien aihe, joka ei koske itseä. Pian koskee. Tässä hiukan lukuja: Taudinmääritystä vaativia muistipulmia on neljännesmiljoonalla suomalaisella. Suurin osa sairastuneista on yli 65-vuotiaita, ja vuoteen 2030 mennessä yli 65-vuotiaita on neljännes väestöstä. Silloin keskivaikeaa tai vaikeaa dementiaa sairastaa 128 ooo suomalaista, kun vielä vuonna 2005 luku oli 85 000. Siis moni unohtelee. Ja vielä useampi miettii, mitä läheisen päässä oikein tapahtuu kun hän ei muista - niin varmaan Irman pojanpoikakin.

"Tulevaisuudessa yhä useammassa perheessä on joku, joka potee muistisairautta", kuvailee neurologian erikoislääkäri Timo Erkinjuntti. (HS Sunnuntai 7.12.2008) 
Fyysisessä mielessä katkelman rytmi rakentuu pitkästä leipätekstikappaleesta ja sitä seuraavasta lyhyestä, lihavoimastani sitaattikappaleesta. Rytmitystä tapahtuu kuitenkin myös toisella tasolla: ilmaisun intensiteetti vaihtuu ensimmäisen ja toisen kappaleen välillä. Leipäteksti sisältää runsaasti "kovaa" numerofaktaa hyvin informatiivisiksi lauseiksi pakattuna. Kertoja jopa varoittaa lukijaa luettelonomaisuudesta (Tässä hiukan lukuja:). Leipätekstin viimeisen virkkeen ja sitä seuraavan sitaatin välillä ilmaisun intensiteetti muuttuu: numeroiden sijaan äänessä on nyt ihminen, joka puhuu vieläpä ihmisistä (läheinen, Irman pojanpoika, perhe). Se vaihtaa tekstin sävyn hyvin inhimilliseksi ja tunteita herättäväksi. Asettumalla lukijan tasolle kertoja ikään kuin huomioi lukijan edeltävää leipätekstiä paremmin.

"Analyyttinen" rytmi. Sitaattien rakennetta hahmottava tehtävä voi pohjata myös jutun analyyttiseen, älylliseen tarkasteluun. Selvennän havaintoani Valituissa Paloissa julkaistulla jutulla, joka on kertomus isän ja pojan metsästysmatkasta Alaskaan. Poika loukkaantuu vuorilla vakavasti, jolloin isä joutuu jättämään tajuttoman poikansa yksin erämaahan apua hakeakseen. Valittujen Palojen A5-kokoisille sivuille taitettuna juttu vie (muutamat mainokset mukaan lukien) 21 sivua. Vaikka isä ja poika ovat jutussa läsnä alusta alkaen, jutun ensimmäinen sitaatti on vasta kahdeksannella sivulla.

\section{- - Jake kiipesi kumpareelle tähystääkseen kanjoniin ja näki rinteessä kaksi ruohoa} syövää pässiä. Ne näyttivät kuitenkin pienenlaisilta.

"Jatketaan matkaa", Rick sanoi. Heidän jatkaessaan kulkuaan puronuomaa ylös Jake vilkuili koko ajan pienemmästä rotkosta havaitsemiaan kahta pässiä. Lopulta hän ilmoitti isälleen haluavansa ampua toisen niistä. (Valitut Palat 8/2008)

Välittömässä kontekstissaan tarkasteltuna sitaatti tuntuu varsin vähäpätöiseltä. Jutun kokonaisrakenteen kannalta sitaatti on kuitenkin ratkaisevassa pisteessä: dramaattiset tapahtumat lähtevät vyörymään pian Rick-isän lyhyen sitaatin jälkeen. Jake päättää ampua toisen pässeistä. Hän pyrkii ampumaetäisyyden päähän, mutta putoaa jyrkänteeltä. Sitaattia edeltävien sivujen aikana jutun kertoja on esitellyt henkilöt (isä Rick ja poika Jake) ja rakentanut näyttämön (metsästysretki erämaassa). Itse sitaatti on merkkinä käännekohdasta - Aristoteleen termein peripetiasta - jonka jälkeen tapahtumat lähtevät peruuttamattomasti uuteen suuntaan eikä paluuta takaisin enää ole (Aristoteles [1977]).

\section{Sitaatti kuljettaa juonta}

Lehtijuttu kertoo peräkkäisistä tapahtumista muodostuvan tarinan. Kirjoittajan juttuun sommittelema juoni sen sijaan ratkaisee, missä järjestyksessä ja millä tavoin tarina lukijan hahmotettavaksi tarjotaan. Juha Rosma (1984) on verrannut elokuvadramaturgiaa käsittelevässä artikkelissaan tarinaa karttaan, johon on merkitty lähtöpiste ja maali. Tässä vertauksessa juoni vastaa reittiä näiden kahden pisteen välillä. 
Samaan loppupisteeseen päätyviä erilaisia reittejä on suunniteltavissa lukematon määrä, eli samasta tarinasta on kehitettävissä useita erilaisia juonikertomuksia.

Koherentissa lehtijutussa kaiken kerrotun täytyy tavalla tai toisella nivoutua yhtenäiseksi kokonaisuudeksi, ja muiden kerronnan keinojen ohella myös sitaatit ovat Rosmaa mukaillakseni - käännöksiä tarinan kartalla: niiden kautta juoni etenee lähtöpisteestä maaliin.

Mitä he siellä tekevät, sairastuneena?

"Elävät siellä. Monella menee huonosti. Jollain saattaa olla kotisairaanhoito, jollain laitoshoito. Mutta laitoshoidossakin on porukkaa, joka ei ole koskaan saanut diagnoosia siitä, miksi on siellä. Se olisi hyvin tärkeää." (HS Sunnuntai 7.12.2008)

Esimerkissä leipäteksti esittää kysymyksen, johon sitaatti vastaa - purkaa luodun jännitteen. Tekstin koherenssia lisää se, että sitaatin ensimmäisen lauseen elliptisiä viittaussuhteita (ketkä elävät? missä siellä?) olisi mahdotonta ymmärtää ilman edeltävää leipätekstiä. Samaan tapaan sitaatti voi edistää juonta tarjoamalla perustelun, kommentin, lisätietoa tai tarkennuksen leipätekstin esittämään asiaan.

Tarinan juoni voi edetä myös pelkkien sitaattien eli dialogin kautta, sillä keskustelun puheenvuorot ovat aina jossain määrin reagointia edelliseen puheenvuoroon ja luovat toisaalta odotuksia tulevasta puheenvuorosta. Keskusteluntutkimuksessa tätä kutsutaan vierusparijäsennykseksi (tarkemmin ks. Tainio 1997). Seuraavassa Valituista Paloista otetussa esimerkissä taidevarkautta selvittävää poliisia (Wittman) haastatellaan siitä, miten hän onnistui hankkimaan jutussa tarkasteltavan ryöstetyn taulun takaisin varkaalta (Kadhum).

- - Kun Kadhum vihdoin palasi hotelliin, hänellä oli taulu mukanaan tiukkaan solmitulla narulla suljetussa punaisessa huopapussissa. "Minulla oli kova homma sen pussin avaamisessa", Wittman kertoo naureskellen. "Huoneessa ei ollut yhtään teräasetta."

Lopulta hän sai paketin auki, ja siinä se oli, varastettu Rembrandt.

"Irrotitko sen kehyksistä jossain vaiheessa?" Wittman kysyi.

"En ole koskenutkaan siihen", Kadhum vastasi.

"Oletko taiteenharrastaja?"

"En. Teen tätä vain rahan vuoksi." (Valitut Palat 2/2009)

Lihavoimassani osassa jutun juonen eteneminen tapahtuu kahdella kysymyksen ja vastauksen sisältävällä vierusparilla. Dialogi on siitä erityislaatuinen kerronnan muoto, että siinä jutun juonen ja tarinan tapahtumien ajankulku yhtyy - tarina etenee ikään kuin reaaliajassa juttua lukiessa (Rimmon-Kenan 1991 [1983], 70). Jälkimmäisestä vierusparista puuttuvat jopa reaaliaikaisuutta ja vuorojenvaihdon etenemistä "rikkovat" johtoilmaukset. Stein $(1995,121)$ on myös huomauttanut, että dialogi jättää paperille usein tyhjää tilaa, mikä nopeuttaa silmän liikkumista sivulla ja luo siten lukijalle tunteen tapahtumien vauhdikkaasta etenemisestä. 
Kolmannessa esimerkissäni tarinankerronnan juoni edistyy siten, että juttuun kirjoitettu kertoja-toimittaja reagoi sitaatissa esitettyyn asiaan, tässä tapauksessa ajattelulla.

"Tytöt, tulkaa tänne, täällä on julkkiksia! Ei uskoisi, mutta näin on! Katsokaa, tuolla oikealla tuo tumma mies. Hän on tv:stä tuttu!"

No, katsotaan. Sehän on Arman Alizad, Iranissa syntynyt vaatturimestari, joka juonsi Moon TV:ssä ilkikurista muotiohjelmaa Dresscode. Tuolla taas istuu Porno-stara-ohjelman toimittaja Sami Hernesaho sekä kanavan pahin rääväsuu Sacha Remling.

"Missä Wallu on?" joku kysyy.

Tosiaan, Moon TV:n tunnetuin kasvo, rocktoimittaja Jani "Wallu" Valpio ei ole paikalla. (Image 6/2003)

Ensimmäisen sitaatin puhuja kehottaa "katsomaan". Kertoja toimii tämän mukaisesti, joskin minä-muodon sijaan passiivilla (katsotaan). Makkonen-Craig (2005) on nimennyt esitystavan dialogiseksi passiiviksi. Hänen mukaansa se on sanomalehtiteksteissä varsin yleinen ja konventionaalinen keino, jolla välitetään paitsi kertojan henkilökohtaista näkökulmaa, myös luodaan kertojan vierelle ikään kuin mukanaolon paikka lukijayleisölle. Dialogisella passiivilla lukija "temmataan" mukaan tarinan tapahtumiin. (emt.) Katkelman jälkimmäisessä sitaatissa "joku" kysyy, missä Wallu on, minkä jälkeen juoni etenee taas kertojan asiaa koskevalla pohdinnalla.

Olen käsitellyt kyseistä sitaatintehtävää - juonenkuljetusta - tässä varsin konkreettisella, tekstirakenteen tasolla. Sitaatteja, erityisesti dialogia, voidaan kuitenkin käyttää myös tarinan syvempää rakennetta edistävänä elementtinä, kuten Gloria Kempton $(2004,53)$ dialogia (kaunokirjallisuudessa) käsittelevässä oppaassaan neuvoo: sitaatti on luonteva tapa kertoa henkilöiden välisestä dynamiikasta ja kiihdyttää tunnetilojen ja tarinan vauhtia jännitteen voimistamiseksi. Tätä funktiota ilmentävät kuudennen sitaatin tehtävän (Sitaatti luonnehtii puhujaansa) yhteydessä antamani juttuesimerkit.

\section{Sitaatti kertoo ympäristöstä}

Sitaateissa puhuu ihminen, ja tosielämässä inmisen puhe tapahtuu aina jossain fyysisajallisessa paikassa. Kaunokirjallis-journalistisille aineistojutuilleni on tyypillistä, että tämä paikka - jota journalistipiireissä kutsutaan lokaatioksi - on monesti juttuihin ilmi kirjoitettu. Sitaateilla lokaation illuusiota voidaan vahvistaa (ks. esim. Silfverbergin haastattelu; Stockwell 2002).

Fyysis-ajallinen ympäristö. IImeisin tapahtumien fyysistä lokaatiota vahvistava piirre ovat sitaattiin valitussa lausunnossa olevat deiktiset pronominit, joiden merkitys määrittyy vain keskustelun kontekstin kautta.

"Tuolla asuu mun mutsi ja faija." Vanhempien talo näkyy puiden takaa, sinne johtaa polku, jonka varteen on laitettu valaisinrivi. "Ja näet sä ton talon, tuolla kalliolla. Siellä asuu broidi." (HS Kuukausiliite 11/2003) 
Sitaattien demonstratiivipronominit (tuolla, ton, siellä) viittaavat tekstistä ulos eli puhujan fyysiseen ympäristöön, siihen ympäristöön, jossa sitaatti on sanottu. Tällä tavoin sitaatit paitsi vahvistavat juttuun kirjoitettua lokaatiota, myös asemoivat toimijoiden fyysisen sijainnin suhteessa tähän lokaatioon. Koska keskustelussa on lähtökohtaisesti vähintään kaksi osallistujaa, keskustelun illuusiota luovat myös näihin osapuoliin viittaavat yksikön 1. ja 2. persoonan pronominit (mun ja sä) sekä verbitaivutukset (näet).

Läsnäoloa jutun lokaatiossa vahvistavat myös muun muassa deiktiset ajan adverbiaalit, jotka vahvistavat jutun kerronnan ja tarinan samanaikaisuuden illuusiota:

Ex-toimitusjohtaja Kristiina Autio tarttuu megafoniin. Vakavan oloinen Autio haluaa kiittää työntekijöitään.

"Olen todella pahoillani siitä, mitä tapahtui...".

"Joo joo, sulla on varmaan jo uusi duuni", joku huutaa väliin.

"Tänään kävin Kluuvin työvoimatoimistossa ilmoittautumassa työttömäksi", Autio kuittaa. (Image 6/2003)

Sosiaalinen ympäristö. Fyysisen ympäristön lisäksi sitaatit voivat kertoa jutun sosiaalisesta ympäristöstä eli lokaatiossa vallitsevasta tunnelmasta ja ihmisten välisen kommunikaation laadusta (ks. esim. Kempton 2004; Jacobi 1991). Seuraava esimerkki on yksi kokonainen anfangeilla erotettu jakso Suomen Kuvalehdessä julkaistusta, Yhdysvaltojen sotasairaalan toimintaa Irakin Bagdadissa seuraavasta jutusta.

Potilas. Vamma. Toimenpide.

Tarkista pupillit, tippa suoneen, täytä lomake.

Nopea sätkä tupakkapaikalla, sitten tulee hoppu.

Takaportista kaasuttaa pölyinen Humwee. Ensiavussa kuullaan jo moottorin ulvonnasta, että tulijoilla on kiire. Hoitajat säntäävät pihalle.

Taisteluauto pysähtyy jarrut kirskuen. Panssaroitu takaovi paukahtaa auki. "Voi

\section{vittu! Avatkaa se saatanan ovi!"}

Amerikkalaisjoukkueen lääkintämies juoksee Humween ympäri ja ryhtyy riuhtomaan toista takaovea. Hoitajat yrittävät auttaa, mutta sotilas tönäisee heidät syrjään. "Painu-

\section{kaa vittuun!"}

Lopulta ovi saadaan auki, ja haavoittunutta aletaan kiskoa ulos. Mies on roteva, oviaukko on ahdas, ja paarit kaatuvat. Lääkintämies paiskaa kypäränsä asvalttiin.

\section{"Vittu saatana!"}

Paarit sisään, potilas pöydälle, verho kiinni.

Kukaan ei ehdi kysyä, mitä on tapahtunut.

Ilmeet ovat tiukat.

Hoitaja katkoo saappaiden nauhat saksilla. Sotilaan jalat ovat kelmeät.

Kersantti Richard Baldwin nousee jakkaralle pöydän viereen. Kädet päällekkäin, ja elvytys alkaa harjaantuneesti. Yksi, kaksi, kolme, neljä, viisi... 
Lääkintämies nielee kyyneliä. "Hän oli tajuissaan, mutta sitten..."

Haavoittuneen alta, lantiosta, valuu verta lattialle.

Hoitajat vaihtavat vuoroa. Elvytys jatkuu: viisi, kymmenen, viisitoista...

Painekone työntää verta laskimoon ja saman tien sirpalehaavasta pöydälle.

Sotilas kuolee. (Suomen Kuvalehti 20/2009)

Tiukan asiasisällön näkökulmasta lääkintämiehen sitaatit, jotka esimerkkikatkelmasta olen lihavoinut, ovat varsin merkityksettömiä. Faktan sijaan sitaatit välittävätkin tietoa juttuun kirjoitetun kohtauksen sosiaalisesta ympäristöstä, ilmapiiristä: kiireestä ja hädästä. Ne toimivat ikään kuin ääninäytteenä paikan päältä. Toki sitaatit kertovat myös lääkintämiehen lähes shokinomaisesta mielentilasta, mutta koska lääkintämies itse ei nouse jutussa merkittävään asemaan - hän ei esiinny muualla jutussa eikä edes hänen nimeään mainita - tarkoitus ei liene rakentaa hänestä sen kummemmin henkilökuvaa.

\section{Sitaatti luo uskottavuutta}

Kuten jo artikkelin alussa totesin, on sitaatin luotettavuutta luova funktio yksi sitaatin keskeisimpiä ellei keskeisin tehtävä, ja se nousikin taajaan esille niin ammattikirjallisuudessa kuin teemahaastatteluissakin. Sitaatin avulla lukija kuulee asian suoraan niiden suusta, jotka ovat lähimpänä aiheen ydintä tai tietävät siitä eniten. Kun puheenpätkä on asetettu sitaatiksi, kirjoittaja antaa lukijalle vakuutuksen, että lausunto on tarkalleen alkuperäisen kaltainen eikä sisällä toimittajan tulkintaa tai muokkausta. Erityisen tarpeen tällainen vakuus on silloin, jos on syytä olettaa, että lukija epäilee asioiden todenperäisyyttä.

Hjallis ei ole vatvonut menneitä exänsä kanssa ikinä, mutta tätä Kuukausiliitteen juttua varten ex-tyttöystävää on haastateltu.

"Ai, mitäs se?" Hjallis kysyy, vähän ujosti, ja punastuu hiukan. (HS Kuukausiliite 11/2003)

Harkimon sitaatti on lyhyt mutta paljon puhuva: katkelmassa Harkimo on herkkä ja varautunut, mikä ei vastaa sitä lähinnä epäsympaattista, osin koomistakin vaikutelmaa, joka Harkimosta on aiemmin jutussa annettu ja joka monilla lukijoilla entuudestaan hänestä todennäköisesti on. Jos kertoja-toimittaja pyrkisi välittämään Harkimon olemuksessa havaitsemansa muutoksen kuvailemalla, lukija saattaisi suhtautua jutun todenperäisyyteen epäillen. Sitaatti sen sijaan tarjoaa lukijalle mahdollisuuden nähdä ja kuulla itse Harkimon reaktio ja tehdä siitä omat päätelmänsä.

Sen lisäksi, että sitaatti luo uskottavuutta lausunnon todenperäisyyteen, kirjaamalla lausunnon sitaatiksi kirjoittaja siirtää vastuun mielipiteestä tai asian paikkansapitävyydestä lausunnon antajalle. On kuitenkin syytä muistuttaa, että juridinen vastuu jutusta säilyy pääsääntöisesti toimittajalla (ja lehden päätoimittajalla), joskin joissain 
tapauksissa rikosoikeudelliseen vastuuseen on Suomessa laitettu myös jutussa haastateltu henkilö (ks. Tiilikka 2008).

Jos kysymystä uskottavuudesta lähestytään puolestaan leipätekstin näkökulmasta, huomataan, että leipätekstissä esitetyt asiat saavat vahvistusta sen henkilön asiantuntija- tai auktoriteettiasemasta, jota leipätekstin ohessa siteerataan (ks. esim. Lundberg 1992). Palataan jo aiemmin sivulla 71 esitettyyn esimerkkiin, jossa neurologian erikoislääkärin Timo Erkinjuntin sitaatti ikään kuin vahvistaa toimittajan leipätekstissään esittelemät numerotiedot ja lisäksi suhteuttaa ne maallikolle helpommin ymmärrettäväksi: muistisairauksien lisääntyminen tarkoittaa siis sitä, että yhä useammassa perheessä joku niitä potee. Vaikka toimittaja olisi voinut tehdä saman taustatyön (kirjallisuuteen tutustuminen ja haastattelut) pohjalta jutun, jossa ei olisi ensimmäistäkään sitaattia tai viittausta lähteisiin mutta joka kuitenkin olisi asiasisällöltään yhtä pätevä, asiantuntija toimii jutussa ikään kuin "totuudentorvena" (Silfverbergin haastattelu).

\section{Sitaatti välittää ainutkertaisuutta ja omakohtaisuutta}

Sitaatti välittää sellaista tietoa alkuperäisestä lausunnosta, jota jutun kirjoittaja ei voisi muilla keinoin yhtä onnistuneesti välittää. Sitaatiksi asetettu lausunto voi olla esimerkiksi sanavalintojen ja lauserakenteiden suhteen sellainen, että sen voima latistuisi, jos se olisi esitetty parafraasina leipätekstissä. Seuraavassa on katkelma Moon TV:n historiasta kertovasta jutusta.

Moon TV teki lukion keskenjättäneestä vantaalaisesta raikulipojasta valtakunnallisen julkkiksen, rockjournalismin Andy McCoyn. Wallu ei oikein itsekään osaa kertoa, kuinka kaikki kävi.

"Se oli täysi yllätys. Ulkopaikkakunnilla ei ollut terveellistä kävellä kadulla. Se oli kuin jumala olisi astunut kehiin. Ei paljon tarvinnut juomia maksella. Pillua sai ja paljon, sehän siinä oli parasta." (Image 6/2003)

TV-kasvo Wallu Valpion puhetyyli esimerkkisitaatissa on sanavalintoineen ja asiasta toiseen etenemisineen hyvin omaperäinen. Jos lausunto pyrittäisiin esittämään epäsuorana kerrontana, siinä voitaisiin säilyttää lähinnä sitaatin sisältöä mutta muotoa tuskin lainkaan. Epäsuoraksi muokkaamisen myötä lausunnosta nimittäin saattaisi tulla turhan epäselvä (Valpion mukaan ulkopaikkakunnilla ei ollut terveellistä kävellä kadulla), banaali (Valpiosta tuntui, kuin jumala olisi astunut kehiin) ja toimittajan leipätekstiin sopimaton (pillu). Joskus suoran lainauksen kääntäminen epäsuoraksi johtaisi melkeinpä kielenvastaisiin lausekummajaisiin. Erityisesti tällainen tilanne tulee vastaan partikkeleista muodostuvia lausumia referoitaessa.

"Aijaa, okei", Hjallis sanoo ja jää miettimään asiaa. (HS Kuukausiliite 11/2003) 
Harry "Hjallis" Harkimon lyhyen sitaatin esittäminen epäsuorana kerrontana muodostaisi erikoisen ja yleiskielen rajoja koettelevan yhdyslauserakennelman: ?Hjallis sanoo, että aijaa, okei, ja jää miettimään asiaa. Tietysti sitaatin voisi korvata parafraasilla, vaikkapa Hjallis kuulostaa hieman yllättyneeltä tiedon vastaanottaessaan. Kiistatta tuollainen referointi olisi kuitenkin epätäsmällisempi, hukkaisi osan henkilöä luonnehtivasta ilmaisupotentiaalistaan (ks. kuudes sitaatin tehtävä) ja olisi pituutensakin puolesta epätaloudellisempi ${ }^{3}$. Referointia Kainuun ja Pohjois-Karjalan murteissa tutkinut Kaija Kuiri (1984) on havainnut, että referointi tapahtuu sitä todennäköisemmin sitaatilla, mitä kiinteämmin tietty funktio on kiteytynyt nimenomaan alkuperäisen lausuman muotoon. Näin siksi, että monet muodon kantamat merkitykset eivät ole parafraasien ulottuvissa.

Muodon tapaan sitaatin ainutlaatuisuus voi perustua myös sitaatin merkitykseen. Erityisesti tarinan henkilön omakohtaiset kokemukset ja tunteet ovat asioita, joihin kenelläkään muulla ei ole pääsyä ja joiden esittäminen on siksi suorana esityksenä uskottavinta ja välittömintä - kuten seuraavassa Harkimolta lainatussa sitaatissa.

"Kun sä teet niin, sulle tulee välillä niin paha olo, että sä haluaisit oksentaa. Sä mietit, että sä teet pahan asian Leenaa kohtaan, ja sit se on kuitenkin niin reilu sua kohtaan... Reilu ja ystävällinen." (HS Kuukausiliite 11/2003)

Vaikka sitaatissa käytetään pronominia sä yleistävänä yksikön toisena persoonana (tarkemmin ks. ISK § 1365), laajemman kontekstin perusteella selviää, että puhuja viittaa sillä nimenomaan itseensä, omiin kokemuksiinsa ja tuntemuksiinsa. Harkimon tilityksen voikin nähdä itsereflektiona, jossa Harkimo arvioi ja luonnehtii itseään. Tällainen funktio lipuu jo kohti kuudetta sitaatin tehtävää, jossa lainausta käytetään puhujansa luonnehtimiseen.

\section{Sitaatti luonnehtii puhujaansa}

Ihminen ilmaisee yksilöllisyyttään ja luo identiteettiään kaikessa tekemisessään, eikä vähiten puheessaan. Lausuman sisältö luonnehtii puhujaansa - mitä hän tietää ja miten tietämäänsä suhtautuu - mutta samoin luonnehtii lausuman muoto: miten puhuja asiansa sanoo ja miten hän ajatuksesta toiseen etenee.

Vaikka puheesta tehtävät päätelmät syntyvät usein varsin tiedostamatta ja ovat vaikeasti sanallisesti määriteltävissä, se, millä tavalla henkilö puhuu, reagoi keskustelussa ja siirtyy ajatuksesta toiseen, luonnehtii puhujaa. Ilmeet ja eleet voivat olla ristiriidassa lausuman sisällön kanssa, jolloin uskomme herkemmin ei-kielellistä viestintää (Valo \& Almonkari 1995). Lehtijuttujen sitaatit ovat kirjoitukseksi siirrettyä puhetta. Vaikka niiden keinot välittää puhuttua kieltä - erityisesti prosodiaa ja siihen liittyviä eleitä ja ilmeitä - ovat niukat, hyvin valittuina ne voivat kertoa puhujan luonteesta, koulutuksellisesta ja maantieteellisestä taustasta, ihmissuhteista, arvoista ja tavasta ajatella kosolti elävämmin ja uskottavammin kuin pitkäkään ker- 
ronta tai kuvailu leipätekstissä. Toisaalta toimittaja tällä tavoin ulkoistaa luonnehdintatyön lukijalle.

Seuraavaa Harry Harkimon henkilökuvajutusta otettua sitaattia on edeltänyt jutun kertojan lista syistä, joiden vuoksi Harkimo "on hankkinut ärsyttävyydellään ja röyhkeydellään kansan epäsuosion ja paljon vihamiehiä". Lopuksi kertoja ehdottaa, että nyt "[h] änellä olisi sopiva hetki katua". Harkimo vastaa seuraavasti:

"Vittu, ei kiinnosta! Joskus tekee jotain hyvää ja joskus tekee jotain huonoo. Mutta ei niitä kannata alkaa katumaan. Tapahtuu mitä tapahtuu, ei sille voi mitään!” (HS Kuukausiliite 11/2003)

Sitaatin propositionaalinen sisältö on melko suppea. Kertoja olisi voinut tiivistää sen epäsuorasti esimerkiksi toteamalla, että Harkimo ei halua katua tekemisiään, koska menneitä ei voi muuttaa. Toki jo se luonnehtisi puhujaa. On kuitenkin ilmiselvää, että Harkimon lausunnon sanatarkka referointi kiroamisineen, lyhyine lauseineen ja argumentointitapoineen (esim. Joskus tekee jotain hyvää ja joskus tekee jotain huonoo. Mutta ei niitä kannata alkaa katumaan.) onnistuu kuvailemaan kosolti monipuolisemmin Harkimon luonnetta ja tapaa reagoida.

Harkimo-jutussa ovat näyttämöllä pääasiassa Harkimo ja hänen kanssaan jutteleva kertoja-toimittaja. Harkimon sitaatit välittävät tietoa keskustelukumppanusten henkilökemioista, ja koska kyseessä on henkilökuva Harkimosta, ei kertoja-toimittajasta, sitaatit kuvailevat nimenomaan Harkimon asennoitumista.

Olohuoneessa on takka, ikkuna aukeaa merelle. Levytelineessä on Eva Dahlgrenia, Pia Nilssonia - ja Katri Helenaa!

"Mitä ihmeellistä siinä on? Mitä sä naurat? Et sä kuuntele Katri Helenaa? Eiks sun kaverit kuuntele Katri Helenaa? Vittu sä tunnet pimeitä ihmisii." (HS Kuukausiliite 11/2003)

Harkimon repliikki paljastaa, että hän asemoi itsensä hieman kertoja-toimittajan yläpuolelle - hän ei häpeä musiikkimakuaan eikä koe tarvetta sitä puolustella. Jutun loppupuolella tunteikkaan, mies miehelle -tyylisesti käydyn avioerokeskustelun jälkeen suhde on juttuun kirjoitetun perusteella kuitenkin varsin tasavertainen:

Verannalla Hjallis sytyttää tupakan, valkoisen Marlboron. Hän on pysynyt uskollisena yksinpurjehduksensa pääsponsorille, Philip Morrisille.

"Elämä on vaikeeta, eiks niin?" Hän sanoo ja hymyilee. "Monilla ihmisillä on näitä samoja ongelmii."

Näin on.

Poltellaan rauhassa, hiljaisuuden vallitessa. - - (HS Kuukausiliite 11/2003) 


\section{Puheen muokkaaminen sitaateiksi}

Tässä luvussa tarkastellaan ammattikirjallisuuden ja teemahaastattelujen perusteella sitä, millä tavoin puhuttua kieltä tulisi kirjallisiksi sitaateiksi muokata. Journalistisessa tekstissä sitaatin tulee perustua mahdollisimman tarkasti siihen, mitä haastateltava on sanonut (esim. Kramer \& Call 2007; Handbook of Magazine Article Writing 2005; Scanlan 2000; Suhola ym. 2005). Suomalaisten journalistien itsesääntelyn ohjenuorana ovat Journalistin ohjeet $2011^{4}$, jotka Julkisen sanan neuvoston (JSN) kannatusyhdistys on laatinut ja joiden pohjalta JSN tulkitsee hyvää journalistista tapaa. Sitaattien muokkaamiseen ohjeissa otetaan kantaa vain yleispätevästi: "Journalistin on pyrittävä totuudenmukaiseen tiedonvälitykseen" (kohta 8). Tarkemmin JSN:n ei ole tarvinnut puheen ja siitä tehdyn sitaatin vastaavuutta pohtia, sillä asiasta ei ole jätetty kanteluita5. Mainittakoon vielä, että JSN on antanut vuonna 1981 haastattelua koskevan periaatelausuman ${ }^{6}$, mutta se ei käsittele jutun kirjoitus- ja editointiprosessia vaan keskittyy lähinnä haastateltavan oikeuksiin. Vertailun vuoksi esimerkiksi Iso-Britannian vastaavan itsesääntelykomission Press Complaints Commissionin sekä Iso-Britannian ja Irlannin yhteisen National Union of Journalistsin eettiset säännöt ovat yhtä niukat ${ }^{7}$.

Kuten aiemmin artikkelissani olen osoittanut, on kiistaton tosiasia, että puhe vaatii muokkausta kirjalliseksi sitaatiksi siirrettäessä. Suurten yhdysvaltalaisten mediatalojen tyylikirjat ottavat sitaattien stilisointiin kuitenkin puristisen kannan. Esimerkiksi The Associated Press (AP) - Stylebook and Briefing on Media Law 2009 (Goldstein 2009) suhtautuu varauksella jopa puolihuolimattomien kielenlipsahdusten korjaamiseen.

Älä koskaan muuta sitaatteja edes vähäisten kielioppivirheiden tai virheellisten sanavalintojen korjaamiseksi. Satunnaiset kielenlipsahdukset voidaan poistaa ellipsejä käyttäen, mutta tämäkin tulee tehdä äärimmäistä varovaisuutta noudattaen. Epäselvissä tilanteissa jätä sitaatti käyttämättä tai pyydä puhujaa selventämään. (Emts. 232, suomennos kirjoittajan.)

Myös New York Times - Manual of Stylebook (1999) ja MLA Handbook for Writers of Research papers (2009) lähestyvät sitaattien muokkaamista AP:n kaltaisella pieteetillä. Voi kuitenkin epäillä, miten aukottomasti tällaisia ohjeistuksia käytännössä toteutetaan. Mielestäni Brooks ynnä muut (2002) esittävätkin aiheellisen kritiikin muistuttamalla, että vaikka ihmiset eivät tavallisesti puhu kirjakielen mukaisia lauseita, ajatuksiaan ylös kirjoittaessaan he todennäköisesti kirjoittaisivat kirjakielisemmin. Toimitustyön oppaiden ehdoton enemmistö suhtautuu sitaattien muokkaamiseen käytännönläheisemmin. Sitaatteja saa ja pitääkin muokata, kunhan lausunnon asiasisältö ja painotukset pysyvät ennallaan (ks. esim. Brooks \& Sissors 2001; Handbook of Magazine Article Writing 2005; Scanlan 2000).

Sitaatit "siivotaan". Molempien aineistojeni perusteella erittäin laajasti jaettu käsitys on, että sanojen puhekielisiä äänneasuja muokataan yleiskielisiksi (tehny $\rightarrow$ teh$n y t$, punanen $\rightarrow$ punainen). Myös sanalipsahdukset (investoida - inventoida) on tapana 
"oikeakielistää" ja spontaanille puheelle tavanomaiset mutta kirjakielelle vieraat suunnittelu- ja editointi-ilmaukset (ks. tarkemmin ISK § 860-862) (eiku, niinku, tietsä, sillee jne.) sekä muminat ja ähkinät poistaa, ellei niillä ole erityistä merkitystä jutun näkökulman kannalta. Lisäksi yleistä on puheen lausumien tiivistäminen, selkeyttäminen, yhdistäminen sekä elliptisten, kontekstistaan merkitystä saavien mutta siitä irrotettuna vaillinaisten lauseiden paikkaileminen muutamilla lisäsanoilla, jotta lukija ymmärtää lausumien merkityksen oikein. Imagen päätoimittaja Mikko Numminen kertoo tavoitteensa olevan, että sitaatit olisivat mahdollisimman aitoja. "Ei siinä mielessä, että ne olisivat täysin puhekieltä - tai jos ihminen puhuu murretta, niin ollaan tietysti aika varovaisia sen kanssa - mutta jos inmisellä on esimerkiksi omintakeisia lauserakenteita tai kiinnostavia sanoja, niin niitä me pyritään käyttämään.” (Nummisen haastattelu)

Kielen rekisterit ja murteet. Puhetta sitaateiksi muokattaessa voidaan törmätä siihen, että puhutun kielen käytäntö ja kirjoitetun kielen normisto ovat ristiriidassa keskenään. Hyväksi esimerkiksi käy kuuluisa kiistapari alkaa tehdä - alkaa tekemään. Vaikka jälkimmäinen on puhutulle kielelle lähes yksinomainen muoto, vain edellinen on kirjakielen (tämänhetkisten) sääntöjen mukaan oikein. Anu Silfverberg (haastattelu) kertoi Helsingin Sanomissa työskennellessään päätyneensä kollegoidensa kanssa siihen, että puhekielinen muoto muutettiin puhesitaatissa kirjakieliseksi. Hänen mukaansa kokemus oli osoittanut, että kirjakielen näkökulmasta virheellisen muodon valitseminen aiheuttaisi ärtyneen palautteen ryöpyn.

Normien erilaisuuden sijaan niiden puutteeseen joutuu vastaamaan silloin, kun haastateltava henkilö puhuu leimallisesti tiettyä murretta, jonka haluttaisiin myös sitaateissa kaikuvan. Murteisille sanoille ei ole vakiintunutta kirjakielistä oikeinkirjoitusasua, minkä vuoksi niin murteen litterointi kuin lukeminenkin on vaikeaa. Taajaan esiin noussut käytäntö on, että murteen annetaan näkyä vain sen leimallisimpien piirteiden litteraatioissa, kuten persoonapronomineissa (minä - mä - mää - mie - miä jne.) sekä omintakeisissa sanoissa ja sanonnoissa, mutta muuten teksti muokataan pitkälti yleiskieliseen asuunsa. Joidenkin henkilöiden kohdalla murteen säilyttäminen on tullut tavaksi (esim. murrerunoilija Heli Laaksonen), toisten kohdalla se alkaa olla jo lähes välttämätöntä.

Jos sä ajattelet vaikka Marja-Liisa Kirvesniemeä, joka aina sanoo mie, niin kun sitä on niin paljon imitoitukin, niin jos lehdessä lukisi, että Marja-Liisa Kirvesniemi sanoo: 'Minä olen nyt elämääni aika tyytyväinen', niin sähän alkaisit epäillä sitä, ajattelisit että se sanoo kuitenkin mie. (Sillantauksen haastattelu)

On kuitenkin muistettava, että suomen oikeinkirjoitus on fonemaattista - tiettyä äännettä vastaa (lähes) aina tietty merkki - jolloin litteroinnissa voidaan pyrkiä sanojen murteelliseen äänneasuun. Siksi murteen muuttamiselle kirjakieleksi ei ole varsinaisesti käytännöllistä perustelua. Toisin on esimerkiksi englannissa, jossa puheen ja kirjoituksen suhde on hyvin kompleksinen, jolloin sanojen ääntämisessä tapahtuvaa variointia on vaikea siirtää ymmärrettävällä tavalla kirjoitukseen. Ne harvat ang- 
loamerikkalaiset kirjoitusoppaat, jotka puhekielisten kirjoitusasujen jäljittelemiseen ottivat kantaa, neuvoivat sitä lähtökohtaisesti välttämään tai toteuttamaan erittäin säästeliäästi ja varovaisuudella, jotta tekstin luettavuus ei kärsisi.

Sitaatin kääntäminen. Kun haastattelu ja jutun kirjoittaminen tapahtuvat eri kielellä, vaikeudet eivät ole murteiden tapaan äänneasun litterointiratkaisujen etsimisessä vaan siinä, mitkä ovat eri kielten ilmausten vastaavuudet. Tällöin ilmaisun hienosyisimmät ulottuvuudet jäävät herkästi uupumaan. "Varsinkin jos kaikki - haastateltavat ja haastattelija - vielä puhuvat huonoa englantia, niin eihän se kauhean vivahteikasta ole" (Sillantauksen haastattelu). Kirjoitusoppaat eivät tähän asiaan ota kantaa ${ }^{8}$. Haastateltavani kertoivat käyttävänsä vieraasta kielestä käännettyjä sitaatteja lukumääräisesti niukemmin ja kerronnallisesti vähäisemmässä roolissa kuin suomenkielisistä lähteistä lainattuja sitaatteja.

Mutta lähtökohdaksi ottaisin sen, että jos ihminen kertoo itsestään jotain englannin kielellä ja se syventää tämän ihmisen persoonallisuutta, niin kyllä se täytyy voida totta kai myös suomeksi kääntää. Ja jos sitä henkilöä useamman tunnin tai pariinkin kertaan haastattelee, niin oppiihan siinä niitä hänen kielensä vivahteita ja merkityksiä jonkin verran. Sitten täytyy yrittää löytää suomen kielestä sanoja, jotka tuovat siihen puheenparteen samanlaista filistä. (Jantusen haastattelu)

Oma lukunsa ovat erinäiset sanaleikit, huudahdukset ja sanonnat, joiden vastineet eri kielillä eivät välttämättä ole sanatarkkoja käännöksiä toisistaan. Toisaalta vieraskielisen tai -kulttuurisen sanonnan korvaaminen merkitykseltään vastaavalla suomalaissanonnalla sisältää myös riskinsä. "Olisihan se hassua, jos sitaatti käännettäisiin niin, että siinä olisi jotain todella suomalaista... että jos lehdessä lukee 'parempi pyy pivossa kuin kymmenen oksalla, Putin totesi'... onhan se vähän huono" (Sillantauksen haastattelu).

Haastattelun fyysinen ympäristö. Kaunokirjallis-journalistisia piirteitä sisältäville jutuille on juttuaineistoni tapaan tavallista, että fyysis-ajalliset tapahtumapaikat on kirjoitettu juttuun ilmi. Tämä puolestaan aiheuttaa herkästi kitkaa suhteessa siihen vaatimukseen, että kaiken jutussa esitetyn täytyy journalismissa olla totta. Niin haastateltavien ajatuksista kuin oppaiden enemmistöstäkin hahmottui varsin selvänä käsitys, että eri aikaan haastattelua ja jopa eri haastatteluissa sanottuja repliikkejä on - ja täytyykin olla - mahdollista poimia ja asettaa juttuun peräkkäisiksi sitaateiksi, jopa samaan sitaattiin. Olisi absurdia, että lukija pitäisi tylsistyttää parituntisen haastattelun tarkalla selostuksella vain sen takia, että haastattelun ensimmäinen ja viimeinen lause ovat jutun aiheen kannalta kertomisen arvoisia. "Jos haastateltava vastaa samaan kysymykseen kahdesti, niin voin esittää ne vastaukset peräkkäin tai jopa samassa sitaatissa. - - Sitaatteja yhdistellessä toimittajan pitää kuitenkin olla tarkkana, ettei hän tee yhdistelemällä vääryyttä haastateltavalle.” (Nummisen haastattelu.) Ehdottomasti vapaamielisimmän näkemyksen esittää Brooksin ynnä muiden (2002) toimitustyön opas, jonka mukaan ei ole mahdotonta, että ellipsin merkillä (esim. kolme pistettä, kaksi ajatusviivaa, tyhjät hakasulkeet tms.) samaan sitaattiin 
voitaisiin istuttaa puheita, jotka on alkujaan sanottu jopa tuntien päässä toisistaan, kunhan sisällölle ollaan uskollisia: "The only questions you must ask yourself in situations like this are: Am I being fair? - - Am I putting quotes together that change what the speaker intended to say?" (emts. 81-82). Suomalaisissa lehtijutuissa törmää silloin tällöin tapaan, että sitaatin ymmärtämisen kannalta tärkeitä tai sen merkitystä selventäviä sanoja lisätään hakasulkeissa sitaatin referaattiosan sisälle. Sen sijaan toimittajan poistamia sanoja, ellipsejä, ei merkitä pisteillä, ajatusviivoilla tai muillakaan tavoin käytännössä koskaan (Rädyn haastattelu).

Vaikka eri aikaan saatujen sitaattien yhdistely on mahdollista sekä haastateltavieni mielestä että valtaosan oppaista mukaan, tähän liitettiin yleisesti tärkeitä reunaehtoja: ensinnäkin, jos sitaatit on poimittu useassa eri kontekstissa sanotuista repliikeistä, lukijan on pystyttävä arvioimaan sitaatin sisältöä oikean kontekstin valossa.

Jos toinen haastattelutilanne on kahvilassa ja toinen saunassa, ja se ihminen sanoo, että 'juuri tällaisena mä pidän itsestäni kauheasti', niin siinä on ero, jos lukijalle jää käsitys, että se on sanottu saunassa, vaikka se olisikin sanottu kahvilassa. (Sillantauksen haastattelu)

Toiseksi, jos juttuun on kirjoitettuna fyysis-ajallinen paikka, lokaatio, jossa toiminta ja puheet tapahtuvat, myös sitaattien kronologian täytyy vastata todellisuutta.

Jos teen haastateltavan kanssa kävelyn ympäri kaupunkia ja kirjoitan kävelyn juttuun auki, niin en voi siirtää repliikkiä dramaturgisista syistä kävelyn lopusta kävelyn alkuun. Pahimmillaan olen kuullut tarinoita, että otetaan kokonaan toisesta haastattelusta materiaalia ja pannaan yhteen sessioon lainauksiksi, ikään kuin ne olisi sanottu yhdessä paikassa ja yhdessä ajassa kaikki. Mun mielestä lukijaa ei pidä kusettaa, vaikka olisi kuinka hyvä tarkoitus. (Rädyn haastattelu)

Haastattelutapahtumien autenttista kronologiaa voidaankin rikkoa vain niissä kohdin juttua, joissa fyysisestä lokaatiosta on kerronnassa luovuttu ja joissa sitaatit sanotaan ikään kuin ajattomassa ja paikattomassa tilassa.

Mutta lukijalle pitää tehdä selväksi, että tämä on nyt taustaa, ettei väitetä, että tämä on tapahtunut samassa lokaatiossa ja samaan aikaan. (Rädyn haastattelu)

\section{Johtopäätökset}

Analyysini osoittaa, että jokaisella sitaatilla on potentiaalia toteuttaa useita eri tehtäviä. Tehtävät vaikuttavat jutun ja kerronnan eri tasoihin, ja kuten artikkelin alkupuolella totesin, monet tehtävistä perustuvat siihen, että sitaatti on alkujaan puhetta (esim. puhekieliset sanat, äänneasut ja rakenteet sekä viittaukset keskusteluympäristöön). Analyysini tuloksena muotoillut sitaatin tehtävät laajentavat kuvaa kaunokirjal- 
lis-journalististen tekstien ilmaisullisista mahdollisuuksista. Samalla niitä vasten voisi jatkotutkimuksena pohtia, hyödynnetäänkö sitaatteja lehtijutuissa tehokkaasti vai onko nykypäivän usein runsaskin sitaattien käyttö lähinnä konventio. Olisi myös mielenkiintoista tarkastella sitaattien funktioita päinvastaisesta suunnasta: millä tavoin sitaatit lukijan lukukokemukseen ja -elämykseen vaikuttavat?

Vaikka tutkin tässä artikkelissa sitaatteja nimenomaan kaunokirjallis-journalistisia piirteitä sisältävissä jutuissa, uskon, että kuusikohtaista tehtävätyökaluani voi soveltaa myös muuntyyppisiin journalistisiin juttuihin. Kaunokirjallisia keinoja hyödyntävät lehtijutut eivät nimittäin rajaudu omaksi lajityypikseen, vaan se, mikä lasketaan kaunokirjalliseksi journalismiksi ja mikä ei, vaatii aina tapauskohtaista arviointia. Kaunokirjallis-journalistiset jutut voivat hyödyntää perinteiselle uutiselle ominaisia kerronnan keinoja, ja vastaavasti myös uutiset ovat varsinkin viime vuosikymmeninä maustuneet yhä enenevissä määrin kaunokirjallisilla kerronnan keinoilla. (LassilaMerisalo 2009; Pietilä 2007; Herkman 2005; Makkonen-Craig 2005.)

Nähdäkseni kaunokirjallisten keinojen lisääntynyt käyttö liittyy journalismissa viime vuosikymmeninä tapahtuneeseen murrokseen, jonka motivaattoreina ovat olleet yleisöryhmien segmentoituminen ja uusien viestintäkanavien ja -teknologioiden nopea leviäminen. Seurauksena puolestaan on ollut tilaaja- ja ilmoitustulojen horjuminen, mikä on pakottanut toimitukset tarkastelemaan tuotoksiaan entistä enemmän yleisön tarpeiden näkökulmasta. (Väliverronen 2009; Hujanen 2009.) Hujasen mukaan (2009; ks. myös Siivonen 2007) tämä näkyy muun muassa siinä, että journalismin odotetaan tulevan lähemmäs lukijaa - olemaan entistä ihmisläheisempää jos kohta vaatimus ymmärretäänkin toimittajien keskuudessa monilla tavoin: yhdelle ihmisläheisyys tarkoittaa koskettavia ja shokeeraavia tarinoita ihmisten yksityiselämästä, toisille yhteiskunnalliseen elämään aktivoivia arvoja ja käytäntöjä (Hujanen 2009, 112). Yksi ihmisläheisyyden ilmentymä on tunteellisuuden ja tunteiden välittämisen lisääntyminen nykyjournalismissa (Pantti 2009).

Väitän, että journalismin murroksen myötä sitaattien asema tulee korostumaan. Sitaatit ovat kirjalliseen asuun saatettua ihmispuhetta, ja ne tuovat jutun henkilöitä lähemmäs lukijaa ja kertovat heistä ja heidän tunteistaan - ja toisaalta herättävät tunteita lukijassa. Hujasen (2009) tutkimushaastattelussaan saama vastaus osoittaa, miten sitaatin luotettavuutta luovasta funktiosta - jonka Miettinen vuonna 1984 tehdyssä oppaassaan mainitsi - on siirrytty ja siirryttävä monifunktioisempaan sitaattien hyödyntämiseen.

Esimerkiksi onnettomuus- ja rikosuutisoinnissa pyritään kuvaamaan asianosaisten tunteita. Haastattelemani päällikkö kertoi esimerkin messurakennuksen katon romahduksesta. Toimitus etsi uutisointiin tunteita, ja ensimmäinen uutissivu keskittyi siihen, miten tapahtumaan osalliset ihmiset kokivat sen. Asiajutut tulivat vasta toisella sivulla. Ennen olisi ehkä kuunneltu, mitä poliisi sanoo, kirjoitettu muistiinpanot ja tehty niiden pohjalta tapahtumajuttu. Nyt olennaista oli tavoittaa paikan päällä olleet ihmiset kokemuksineen. (Hujanen 2009, 119.) 
Poliisin haastattelusitaattien kautta lukija olisi saanut kuulla sanatarkasti, mitä kerrottavaa tällä on onnettomuuteen liittyvistä "tärkeistä kysymyksistä". Tapahtumapaikalla olleiden ihmisten haastattelusitaattien kautta lukijalle sen sijaan välittyy ensikäden tietoa henkilöiden ainutkertaisista kokemuksista, tuntemuksista ja mielentilasta. Mikäli jutun kerronnassa ollaan reportaasinomaisesti onnettomuusnäyttämöllä, sitaatit voivat myös vahvistaa tätä lokaatiota. Tietysti niiden kautta myös edistetään tarinan juonta ja luodaan juttuun rakennetta.

Journalismin murros on luonut myös toisenlaisia haasteita, joiden seurauksia artikkelini alatutkimuskysymys sivuaa. Taloudellisten haasteiden myötä mediakentän sisäinen kilpailu lukijoista on kiristynyt (esim. Väliverronen 2009). Skuuppien metsästys, epäterve kilpailu toimittajien ja tiedotusvälineiden välillä sekä naiivi luottamus anonyymeihin lähteisiin ovat johtaneet juttujen plagiointeihin ja jopa niiden silkkaan sepittämiseen (Allan 2005, 4-5). Tämä on ehdottomasti riski myös sitaattien oikeellisuudelle, varsinkin, kun mitään yleistä ja yhteistä ohjeistusta puheen muokkaamisesta sitaateiksi ei ole. Oma toimitustyön etiikan rajoja koetteleva ilmiönsä ovat asiakaslehdet, jotka ovat viime vuosina kasvattaneet suosiotaan ja joihin lukeutuvat lukijamäärillä laskettuna Suomen suurimmat aikakauslehdet ${ }^{9}$. Jotkut asiakaslehdistä ovat allekirjoittaneet JSN:n perussopimuksen, ja monesti asiakaslehdet tehdään samalla pieteetillä kuin perinteiset journalistiset yleisölehdetkin. Silti asiakaslehdissä tietojen oikeellisuus - minkä muassa myös sitaattien autenttisuus - ei perustu journalistiseen totuudentavoitteluun vaan kustantajatahon etuun. Samaan ongelmaan törmää myös erinäisissä jäsenlehdissä.

Kysyin sekä tähän artikkeliin haastatelluilta että niiltä toimittajilta, jotka ovat olleet kuuntelemassa luentojani ${ }^{10}$ artikkelin aiheesta, ovatko he antaneet tai saaneet ohjeistusta sitaattien käytöstä tai siitä, miten puhetta tulisi sitaateiksi muokata. Muutamaa pientä ohjeistusta lukuun ottamatta (esim. juttu halutaan kertoa ihmisen kautta ja siksi ensimmäinen sitaatti toivotaan laitettavan lähelle jutun alkua) asiasta ei ollut keskusteltu. Nykytrendi on, että tiedotusvälineiden omia toimituksia pienennetään ja avustajien käyttöä vastaavasti lisätään. Ensinnäkin tällainen kehitys vie kirjoittavan toimittajan entistä kauemmas toimitusten sitaattiohjeistuksista - mikäli sellaisia edes käytäväkeskustelun tasolla on. Toiseksi vapaalle toimittajalle eli yrittäjälle on työsuhteista toimittajaakin tärkeämpää, että juttu on hyvä eli myyvä. Kun kyse on omasta toimeentulosta, kasvanee kiusaus parannella totuutta vetävämmän tarinan toivossa.

Lisäksi suomalaisissakin toimituksissa ollaan soveltavasti siirtymässä perinteisestä keskieurooppalaisesta toimittajakeskeisyydestä kohti angloamerikkalaista keskitettyä työtapaa, jossa jutun työstöön ottaa osaa toimittajan lisäksi alusta asti myös käsittelijä, kenties kuva- ja ulkoasutoimittajakin (Töyry 2009). Mitä tapahtuu sitaattien totuudenmukaisuudelle, jos toimittaja on jutun pääasiallinen tiedonhankkija mutta tekstiä - sitaatit mukaan lukien - kirjoittavat ja editoivat myös ne, jotka eivät ole alkuperäisessä haastattelu tai havainnointitilanteessa olleet - ilman yhteisesti sovittua tapaa puheen muokkaamisesta?

En peräänkuuluta sääntöjä ja sääntöjen vahtijoita, koska se kahlitsisi journalistiseen kirjoittamiseen enemmän tai vähemmän sisältyvän luovuuden aspektin - sen 
mikä erottaa journalismin tiedotteista eli yksinomaan informaatiota välittävistä teksteistä. Sen sijaan kirjoittajien ja tiedotusvälineiden tulisi muistaa ja kunnioittaa sitaattimerkkien alkuperäistä luonnetta: kyseessä ei ole pelkästään kerronnallinen keino vaan merkintätapa sille, että teksti perustuu tosielämässä sanottuun.

Journalistisissa sitaateissa totuuden täytyy olla arvo sinänsä. Sitaattien parantelu ja sepittäminen vesittävät monia sitaateille sisäistettyjä tehtäviä. Ajan kanssa tällainen toiminta nakertaa lukijoiden luottamusta journalistiseen ja journalistista muistuttavaan ilmaisuun, mikä lopulta aiheutuu haitaksi kaikille alalla mukana oleville.

\section{Viitteet}

1 Tarkoitan narratologialla tutkimuksessani nimenomaan kirjallisuustieteessä harjoitettua ns. klassista narratologiaa, joka pohtii kertomuksen, kerronnan ja niitä välittävän kertojan ilmenemistä tarinoissa. Kielitieteellinen narratologian tutkimus on puolestaan perinteisesti syventynyt hahmottamaan kaikista teksteistä löydettävissä olevaa yhtenäistä "kerronnan syvärakennetta", joka kussakin tekstilajityypissä ja edelleen tekstissä ilmentyy eri tavoin mutta kuitenkin tiettyä sekventiaalisuutta uusintaen (ks. Labov 1972).

2 Lainausmerkkien avulla voidaan sitaatiksi merkitä kokonaisen lauseen sijaan vain tietty osuus muilta osin epäsuorasta referoinnista (Wallu kertoi olevansa "ihan siinä uimarannan vieressä", vaan eipä näy.). Varsinkin jos lainausmerkeissä on vain sana tai pari, sillä on usein myös ironisoiva tai muu referoijan asenteen esille tuova funktio (Hän sanoi, että sivistys on hänelle "synnynnäinen piirre”.) (ISK §1460). On myös tilanteita, joissa referaattiosa ja sitä seuraava johtoilmaus näyttäisivät muotonsa puolesta sitaatilta mutta joissa referaattiosaa eivät kehystä lainausmerkit (No, ensin pitää saada Irmalle diagnoosi, tohtori sanoo.). Molemmat edellä mainituista tapauksista olen rajannut tarkasteluni ulkopuolelle.

3 Kielifilosofi Paul Grice (1969) on määritellyt neljä sujuvan kielenkäytön periaatetta, joista yksi määrän maksiimi - liittyy kielen taloudellisuuteen: puhuja ei saa kertoa asiasta liian vähän muttei myöskään liikaa.

4 Ks. www.journalistiliitto.fi/pelisaannot/journalistinohjeet (luettu 25.11.2011)

5 JSN:n valmistelevan sihteerin Ilkka Vänttisen ja neuvoston sihteerin Nina Porran haastattelu marraskuussa 2009.

$6 \quad$ Ks. www.jsn.fi/periaatelausumat/haastattelu (luettu 25.11.2011)

$7 \quad$ Ks. National Union of Journalists (www.nuj.org.uk) ja Press Complaints Commission (www.pcc.org. uk).

8 Koska kääntämisen ongelmatiikka on varsin samankaltaista tekstigenrestä huolimatta, lehtijuttujen kääntämiseen liittyvää käypää opastusta löytyisi varmaankin kääntämistyötä yleisesti käsittelevästä kirjallisuudesta.

9 Levikintarkastus Oy (2011). Suomalaiset lukevat lehtiään monella tavalla. www.levikintarkastus.fi/ mediatutkimus/KMT\%2OLukija\%20-tiedote\%20syyskuu\%202011.pdf (luettu 22.10.2011.)

10 Pidin lokakuussa 2011 luennon sitaattien tehtävistä sekä Journalistiliiton free-osaston kutsumana Helsingin Pressiklubilla että Journalistisen kulttuurin edistämissäätiö JOKES:in järjestämässä Tarinallisuuspajassa Tuusulan Krapissa.

\section{Lehtijuttuaineisto}

Kadotettua aikaa etsimässä (Anu Silfverberg) HS Sunnuntai 7.12.2008

Mahdoton valinta (Chris Davis) Valitut Palat 8/2008

Mies pilakuvassa (Teppo Sillantaus) HS Kuukausiliite 11/2003

Rakkikoirat - Moon TV:n tarina (Ilkka Karisto) Image 6/2003

Ryöstö (Simon Worrall) Valitut Palat 2/2009

Teho-osasto, Bagdad (Jari Lindholm) Suomen Kuvalehti 20/2009 


\author{
Haastattelut \\ Jantunen, Jyrki (Suomen Kuvalehden toimituspäällikkö) 14.5.2009 \\ Numminen, Mikko (Imagen päätoimittaja) 23.3.2009 \\ Riikinsaari, Anni-Marja (Valittujen Palojen toimituspäällikkö) 8.5.2009 \\ Räty, Panu (vapaa toimittaja ja kouluttaja) 15.6.2009 \\ Silfverberg, Anu (vapaa toimittaja ja kirjailija, työskennellyt Helsingin Sanomissa) 24.3.2009 \\ Sillantaus, Teppo (Helsingin Sanomien Kuukausiliitteen toimituspäällikkö) 14.5.2009
}

\title{
Ammattikirjallisuusaineisto
}

Blundell, William E. (1988). The Art and Craft of Feature Writing. New York: Plume.

Boynton, Robert S. (toim.) (2005). The New New Journalism. New York: Vintage Books.

Brooks, Brian S. \& Sissors, Jack Z. (2001). The Art of Editing (Seventh edition). Boston: Allyn and Bacon.

Brooks, Brian S.; Kennedy, George; Moen, Daryl R. \& Ranly, Don (The Missouri Group) (2002). News Reporting and Writing (Seventh edition). Boston: Bedford.

Bruun, Mikko; Koskimies, Ilkka \& Tervonen, Ilkka (1986). Uutisoppikirja. Helsinki: Tammi.

Clark, Roy Peter (2006). Writing Tools - 50 Essential Strategies for Every Writer. New York: Little, Brown and Company.

Dick, Jill (1994). Writing for Magazines. London: Bloomsbury Publishing.

Flaherty, Francis (2009). The Elements of Story - Field Notes on Nonfiction Writing. New York: HarpenCollins.

Frost, Chris (2002). Reporting for Journalists. London: Routledge.

Goldstein, Norm (2009). Associated Press - Stylebook and Briefing on Media Law. New York: Basic Books.

Handbook of Magazine Article Writing (All New Second Edition) (2005). Michelle Ruberg (toim.). Ohio: Writer's Digest Books.

Harrigan, Jane T. (1993). The Editorial Eye. New York: University of New Hampshire, St. Martin's Press.

Hennessy, Brendan (1989). Writing Feature Articles (A Practical Guide to Methods and Markets. Oxford: Heinemann Professional Publishing.

Hennessy, Brendan \& Hodgson, F. W. (1998). Journalism - A Manual of Tasks, Projects and Resources. St. Louis: Focal Press.

Jacobi, Peter P. (1991). The Magazine Article. Bloomington: Indiana University Press.

Kempton, Gloria (2004). Dialogue - Techniques and exercises for crafting effective dialogue. Cincinnati: Writer's Digest Books.

King, Stephen (2000). On Writing - A Memoir of the Craft. London: Hodder and Stoughton.

Kotilainen, Lauri (1989). Hyvä lehtijuttu - kirjoittajan opas. Kuopio: MinnaPress.

Kotilainen, Lauri (2003). Parempi lehtijuttu. Helsinki: Inforviestintä.

Kramer, Mark \& Call, Wendy (toim.) (2007). Telling True Stories - a nonfiction writers' guide from the Nieman Foundation at Harvard University. London: Plume Books.

Lamott, Anne (1995). Bird by Bird - Some Instructions on Writing and Life. Peterborough: Anchor Books.

Lanson, Jerry \& Stephens, Mitchell (2008). Writing and Reporting the News (Third edition). New York: Oxford University Press.

Lundberg, Tom (1992). Tuhannen taalan juttu. Jyväskylä: Weilin-Göös.

Lundberg, Tom (2001). Kirjoita, vaikuta, menesty! Helsinki: WSOY.

Miettinen, Jorma (1984). Toimitustyö. Helsinki: Gaudeamus.

Mill, David (2005). Content is King. Oxford: Butterworth-Heinemann.

MLA Handbook for Writers of Research papers (Seventh edition) (2009). New York: Modern Language Association.

New York Times - Manual of Style and Usage (1999). New York: Three Rivers Press.

Okkonen, Antero (1974). Toimittajan työ I. Hämeenlinna: Karisto. 
Passante, Christopher K. (2007). The Complete Idiot's Guide to Journalism. Blacktown: Alpha Books.

Rentola, Marketta (1999). Kirjoita hyvin. Helsinki: Tammi.

Räty, Panu (1998). Henkilökuva ajan kuvana. Teoksessa: Kantola, Anu \& Mörä, Tuomo (toim.) Journalismia! Journalismia? Porvoo: WSOY, 137-150.

Scanlan, Christopher (2000). Reporting and Writing - Basics for the 21st Century. New York: Oxford University Press.

Stein, Sol (1995). Stein on Writing. New York: St. Martin's Griffin.

Suhola, Aino; Turunen, Seppo \& Varis, Markku (2005). Journalistisen kirjoittamisen perusteet. Helsinki: Finn Lectura.

Töyry, Maija; Räty, Panu \& Kuisma, Kristiina (2008). Editointi aikakauslehdessä. Helsinki: Taideteollinen korkeakoulu.

Uimonen, Taina (2010). Kirjoita kiinnostavasti. Helsinki: Infor.

Wray, Cheryl Sloan (1996). Writing for magazines - A Beginner's guide. Lincolnwood: NTC Publishing Group.

\section{Kirjallisuus}

Allan, Stuart (2005). Introduction: Hidden in plain sight - journalism's critical issues. Teoksessa: Allan, Stuart (toim.). Journalism: critical issues. Berkshire \& New York: Open University Press, 1-15.

Aristoteles [1977]. Runousoppi. Suomentanut Pentti Saarikoski. Helsinki: Otava.

Clayton, Joan (1994). Interviewing for Journalists. London: Piatkus.

Genette, Gérard (1980 [1972]). Narrative Discourse. An Essay in Method. [Discours du récit.] Ranskan kielestä kääntänyt Jane E. Lewin. Blackwell. Oxford.

Grice, Paul H. (1969). Utterer's Meaning and Intention. - The Philosophical Review 78, 147-177.

Haakana, Markku \& Kalliokoski, Jyrki (2005) (Toim.). Referointi ja moniäänisyys. Helsinki: SKS.

Haapanen, Lauri (2010). "Ei vittu, mennään röökille" - Tutkimus sitaattien tehtävistä ja tekemisestä kaunokirjallis-journalistisissa lehtijutuissa. Pro gradu -tutkielma. Suomen kielen, suomalaisugrilaisten ja pohjoismaisten kielten ja kirjallisuuksien laitos.

Hemánus, Pertti (1990). Journalistiikan perusteet. Johdatus tiedotusoppiin 2. Helsinki: Yliopistopaino.

Hemánus, Pertti (1995). Opettaako journalistia Siperia vai tieto-oppi? Teoksessa: Sana, Elina (toim.) Tietoopista mediapeliin - journalismin tutkimuksen näkökulmia. Helsinki: WSOY, 27-46.

Herkman, Juha (2005). Kaupallisen television ja iltapäivälehtien avoliitto. Median markkinoituminen ja televisioituminen. Tampere: Vastapaino.

Hirsjärvi, Sirkka \& Hurme, Helena (2008). Tutkimushaastattelu: Teemahaastattelun teoria ja käytäntö. Helsinki: Gaudeamus.

Hujanen, Jaana (2009). Kiinnostavaa vai tärkeää? Ihmisläheisen journalismin kaksi polkua. Teoksessa: Väliverronen, Esa (toim.). Journalismi murroksessa. Helsinki: Gaudeamus, 112-128.

ISK = Iso suomen kielioppi (2004). Hakulinen, Auli; Vilkuna, Maria; Korhonen, Riitta; Koivisto, Vesa; Heinonen, Tarja Riitta \& Alho, Irja. Helsinki: SKS:n toimituksia 950.

Järventaus, Kaarina (1996). Oikeakielisyydestä sanomalehdessä. Virittäjä 100, 567-570.

Kalliokoski, Jyrki (2005). Referointi ja moniäänisyys kielenkäytön ilmiönä. Teoksessa: Haakana, Markku \& Kalliokoski, Jyrki (toim.) Referointi ja moniäänisyys. Helsinki: SKS, 9-42.

Kauppinen, Anneli \& Laurinen, Leena (1988). Tekstioppi. Johdatus ajattelun ja kielen yhteistyöhön. Helsinki: Kirjayhtymä.

Koski, Mauno (1985). Toiseen tekstiin viittaaminen nykyisessä kirjasuomessa. Teoksessa: Koski, Mauno (toim.). Lauseita ja ajatuksia. Turku: Åbo Akademi, finska Institutionen: Fennistica 5, 70-179.

Koskimies, Rafael (1962). Yleinen runousoppi. Helsinki: Otava.

Kuiri, Kaija (1984). Referointi Pohjois-Karjalan ja Kainuun murteissa. Helsinki: SKS:n toimituksia 405.

Labov, William (1972). Language in the Inner City: Studies in Black English Vernacular. Philadelphia: University of Pennsylvania Press.

Lassila, Maria (2001). Faktaa fiktion keinoin. Nonfiktiota Helsingin Sanomien Kuukausiliitteessä ja Imagessa. Pro gradu -tutkielma. Jyväskylän yliopiston viestintätieteiden laitos.

Lassila-Merisalo, Maria (2009). Faktan ja fiktion rajamailla. Kaunokirjallisen journalismin poetiikkaa suomalaisissa aikakauslehdissä. Jyväskylä: Jyväskylä studies in humanities 113. 
Makkonen-Craig, Henna (1996). Yleispuhekielisyydet lehtikielessä. Pro gradu -tutkielma. Helsingin yliopiston suomen kielen laitos.

Makkonen-Craig, Henna (1999). Speech Quotations in Newspapers as a Form of Language Use. Teoksessa: Haukioja, Timo \& Herlin, llona \& Miesvaara, Matti (toim.) SKY Journal of Linguistics. Helsinki: The Linguistics Association of Finland. Volume 12, 111-144.

Makkonen-Craig, Henna (2005). Toimittajan läsnäolo sanomalehtitekstissä. Näkökulmia suomen kielen dialogisiin passiivilauseisiin. Helsinki: SKS.

McKee, Robert (1998). Story. Substance, Structure, Style, and the Principles of Screenwriting. London: Methuan.

Nissi, Emmi (2010). Täältä tulee tarina - Feature-journalismin jutturakenteet ja ilmaisukeinot kirjoitusoppaissa ja lehtijutuissa. Pro Gradu -tutkielma. Tampereen yliopiston tiedotusopin laitos.

Nousiainen, Anu (1998). Reportaasin renessanssi. Teoksessa: Kantola, Anu \& Mörä, Tuomo (toim.). Journalismia! Journalismia? Porvoo: WSOY, 117-136.

Nylund, Mats (2006). Journalism's Vitality. On the Narrative Functions of Quotes. Teoksessa: Ekström, Mats; Kroon, Åsa \& Nylund, Mats (toim.). News from the Interview Society. Göteborg: Nordicom.

Palmgren, Marja-Leena (1986). Johdatus kirjallisuustieteeseen. Helsinki: WSOY.

Pantti, Mervi (2009). Tunteellisempaa journalismia. Teoksessa: Väliverronen, Esa (toim.). Journalismi murroksessa. Helsinki: Gaudeamus, 193-206.

Pientilä, Antti-Pekka (2007). Uutisista viihdettä, viihdettä uutisista. Median muodonmuutos. Helsinki: Art House.

Rentola, Ilkka (1983). Normaalijournalismin säännöt. Yhdysvaltalaisen journalismin oppikirjallisuuden esittämän ideaalityypin tarkastelua. Tampere: Tampereen yliopiston tiedotusopin laitoksen julkaisuja, sarja A47.

Rimmon-Kenan, Shlomith (1991 [1983]). Kertomuksen poetiikka. [Narrative Fiction. Contemporary Poetics.] Suomentanut Auli Viikari. Tietolipas 123. Helsinki: SKS.

Rosma, Juha (1984). Johdatus elokuvadramaturgiaan. Teoksessa: Juha Rosma (toim.) Elokuvadramaturgian salaisuudet. Hyvinkää: Suomen elokuvasäätiö, 9-109.

Siivonen, Jonita (1999). Stor Anna, Liten Anna och tio andra personporträtt. Om innehållsliga och språkliga mönster i en mediegenres kvinnobeskrivningar. Helsingfors: Forskningsinstitutet, Svenska social- och kommunalhögskolan vid Helsingfors universitet. SSKH Skrifter 11.

Siivonen, Jonita (2007). Personporträttet som tidningsgenre. En närläsningsstudie med fokus på innehållsliga teman, berättarkonventioner och kön.. Helsingfors: Forskningsinstitutet, Svenska social- och kommunalhögskolan vid Helsingfors universitet. SSKH Skrifter 25.

Stockwell, Peter (2002). Cognitive Poetics - An Introduction. London and New York: Routledge.

Tainio, Liisa (toim.) (1997). Keskustelunanalyysin perusteet. Tampere: Vastapaino.

Tammi, Pekka (1992). Kertova teksti. Esseitä narratologiasta. Helsinki: Gaudeamus.

Tervonen, Ilkka (1986). Objektiivisuus ja informatiivisuus. Journalismin tiedollisten ominaisuuksien tarkastelua kahden käsitteen kannalta. Tampere: Tampereen tiedotusopin laitoksen julkaisuja, Sarja A55.

Tiilikka, Päivi (2008). Journalistin sananvapaus. Helsinki: WSOYpro.

Tiittula, Liisa (1992). Puhuva kieli - Suullisen viestinnän erityispiirteitä. Loimaa: Oy Finn Lectura Ab.

Töyry, Maija (2009). Lukijalähtöisyys aikakauslehtijournalismissa. Teoksessa: Väliverronen, Esa (toim.). Journalismi murroksessa. Helsinki: Gaudeamus, 129-149.

Valo, Maarit \& Almonkari, Merja (1995). Puheviestinnän tietoa ja taitoa. Otava: Keuruu.

Van Dijk, Teun A. (1988). News as Discourse. London: Lawrence Erlbaum Associates.

Väliverronen, Esa (2009). Journalismi kriisissä. Teoksessa: Väliverronen, Esa (toim.). Journalismi murroksessa. Helsinki: Gaudeamus, 13-31. 